\title{
Spontaneous Coronary Artery Dissection and Left Ventricular Diverticulum. A Rare Association
}

\author{
Jorge Antonio Cervantes-Nieto ${ }^{1}$, Luis Mario Gonzallez-Galvan ${ }^{1}$ and Nilda Espinola-Zavaleta ${ }^{2,3 *}$ \\ ${ }^{1}$ Department of Medical Teaching, National Institute of Cardiology Ignacio Chavez, Mexico \\ ${ }^{2}$ Department of Nuclear Cardiology, National Institute of Cardiology Ignacio Chavez, Mexico \\ ${ }^{3}$ Department of Echocardiography, ABC Medical Center, Mexico
}

Submission: January 10, 2019; Published: February 21, 2019

*Corresponding author: Nilda Espinola-Zavaleta, National Institute of Cardiology Ignacio Chavez, Juan Badiano № 1, Colonia Sección XVI, Tlalpan, C. P. 14030 , Mexico City, Mexico

Keywords: Coronary Artery; Left ventricular diverticulum; Drug addiction; Diaphoresis; Dyspnea; Rhythmic heart; Pericardial rub; Cardiothoracic index

\section{Clinical Case}

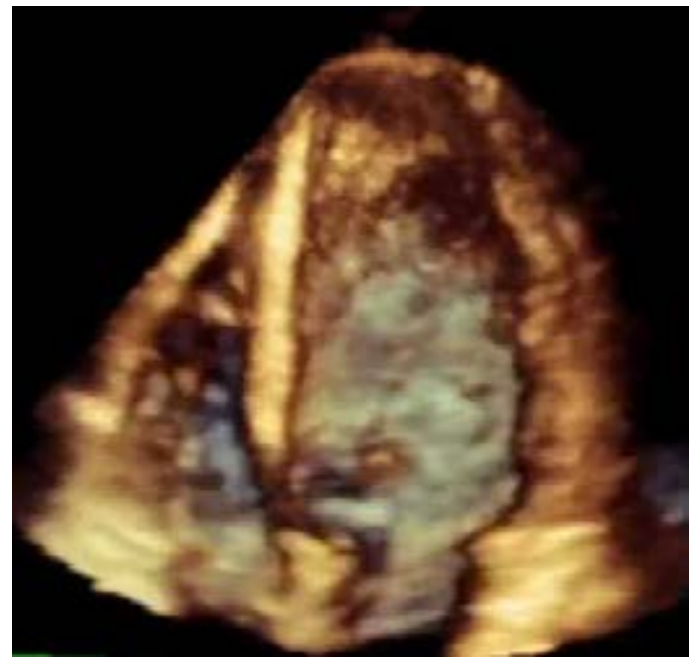

Male, 20 years-old, without background of drug addiction. He came to emergency department, for chest pain with intensity 8/10, profuse diaphoresis and dyspnea. Physical examination revealed rhythmic heart sounds, physiological splitting of the second noise and pericardial rub. Laboratory analysis with reactive protein $\mathrm{C}$ of

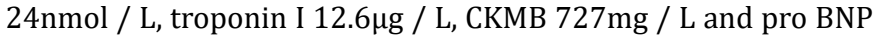
1200pg / ml. ECG in sinus rhythm, with QS in ID, VL, V1-V6 and ST-segment elevation in these leads and ST segment depression in DII, DIII, VF (Figure 1A). Chest x-ray with cardiothoracic index of 0.58 and pulmonary venocapillary hypertension. Transthoracic echocardiogram showed left ventricular dilation, apical dyskinesia with thrombus (Figures 1B-C, Clips 1 \& 2), septal akinesia and hypokinesia of middle segments and ejection fraction of $35 \%$.

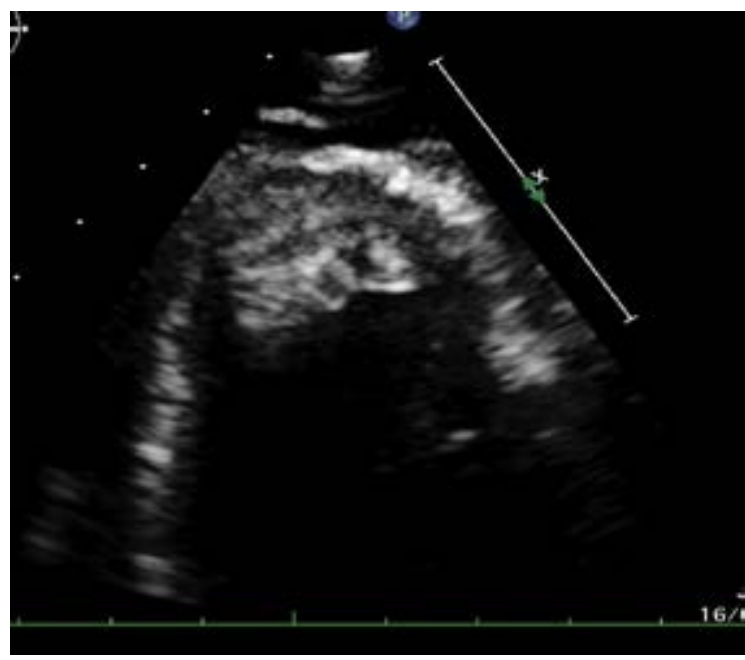

Coronary angiography demonstrated proximal dissection of Left Anterior Descending Artery (LDA) (Figure 1D), treated with zotarolimus-eluting stent (Figure 1E) and ventriculography with apical thrombus and ventricular diverticulum (Figure $1 \mathrm{~F})$. Double platelet antiaggregation and anticoagulation were started. Coronary angiotomography demonstrated permeable stent in proximal LDA, presence of Left Ventricular Diverticulum (LVD) in inferoseptal wall (Figures 2A \& B), anteroseptal and apical infarction, apical and mural thrombus in apical third of anterior wall. The rheumatologist sought to rule out primary antiphospholipid syndrome. Spontaneous Dissection of Coronary Arteries (SDCA) is an unusual cause of acute coronary syndrome. The incidence of SDCA varies from $0.1 \%$ to $1.1 \%$ by angiography. Systematic analysis of all published cases concluded: 


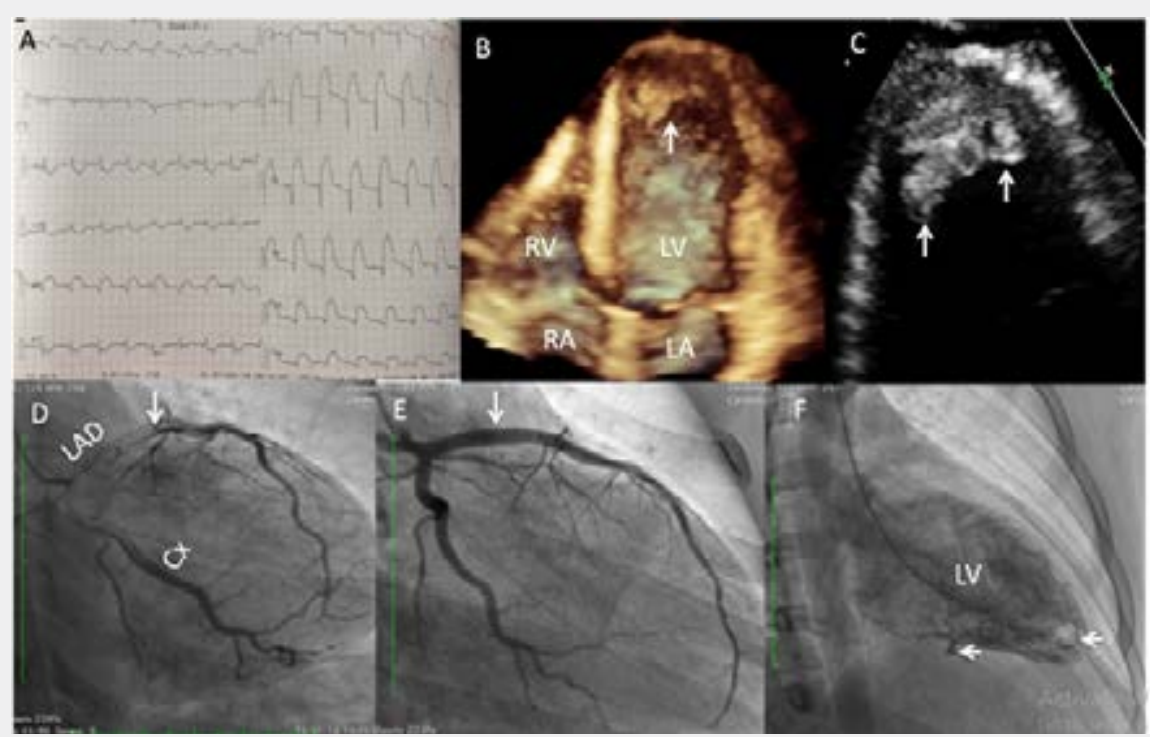

Figure 1: A- ECG with QS wave and ST segment elevation in DI, VL, V1-V6 and ST segment depression in DII, DIII, VF. B- Threedimensional four-chamber-view showing apical dyskinesis with thrombus (white arrow). C- Zoom of apical thrombus (white arrows). DCoronary angiography with proximal dissection of LAD (white arrow). E- Dissection of LAD successfully treated with zotarolimus-elutingstent (white arrow). F- Ventriculography with apical thrombus (head arrow) and LVD (head arrow).

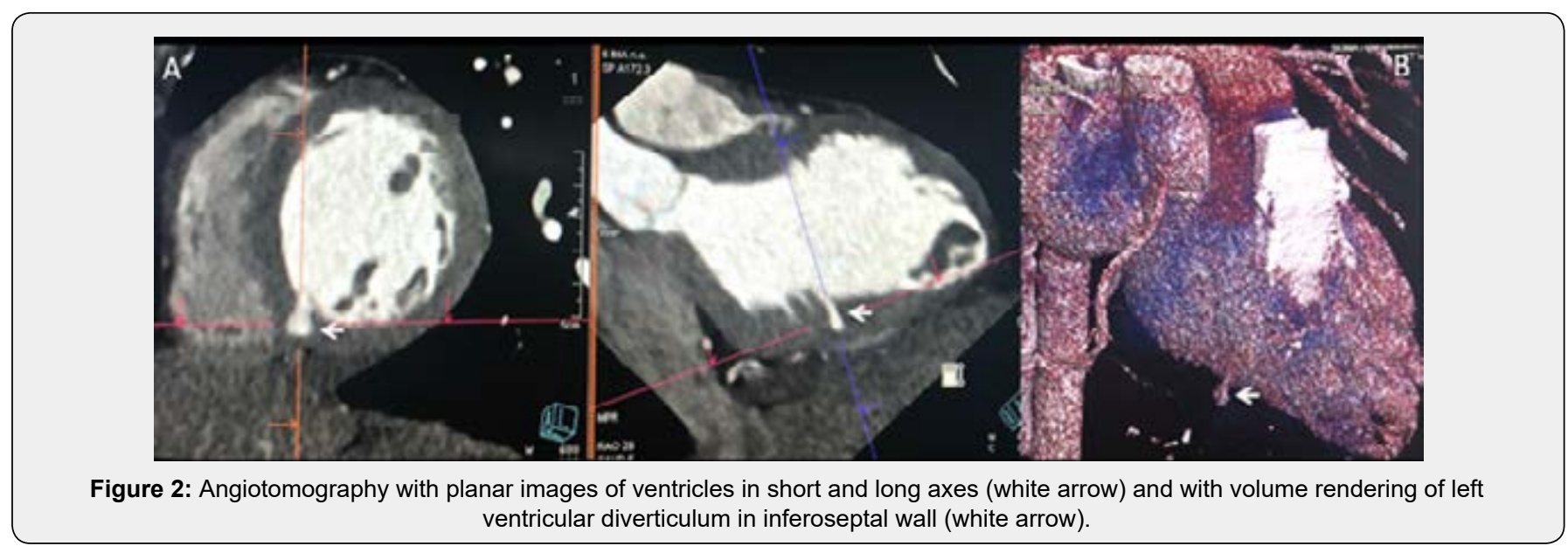

A. Approximately $20 \%$ of cases were diagnosed postmortem and the rest by coronary angiography

B. Isolated coronary involvement was the most frequent lesion

C. Early intervention was superior to conservative treatment

D. Administration of thrombolytics (before diagnosis of SCAD) worse this condition in $60 \%$ of patients [1].

Ventricular diverticula are sacculations of myocardial wall that are presented by an embryological failure of the ventricular muscle. Its prevalence is 0.02 to $0.04 \%$ of all cardiac malformations. They can evolve asymptomatically or present systemic embolization, heart failure, valvular insufficiency, ventricular arrhythmia and sudden death when there is spontaneous rupture of diverticulum [2]. Coexistence of spontaneous dissection of coronary artery with LVD hasn't been reported previously.

\section{References}

1. Shamloo BK, Chintala RS, Nasur A, Ghazvini M, Shariat P, et al. (2010) Spontaneous coronary artery dissection: Aggressive vs conservative therapy. J Invasive Cardiol 22(5): 222-228.

2. Treistman B, Cooley DA, Lufschanowski R, Leachman RD (1973) Diverticulum or aneurysm of left ventricle. Am J Cardiol 32(1): 119123. 


\section{Your next submission with Juniper Publishers will reach you the below assets}

- Quality Editorial service

- Swift Peer Review

- Reprints availability

- E-prints Service

- Manuscript Podcast for convenient understanding

- Global attainment for your research

- Manuscript accessibility in different formats

( Pdf, E-pub, Full Text, Audio)

- Unceasing customer service

Track the below URL for one-step submission https://juniperpublishers.com/online-submission.php 